\title{
$5-2001$
}

\section{Assessment and Accountability Across the 50 States}

Margaret E. Goertz

University of Pennsy/vania, Pegg@gse.upenn.edu

Mark Duffy

Follow this and additional works at: https://repository.upenn.edu/cpre_policybriefs

Part of the Educational Assessment, Evaluation, and Research Commons, and the Education Policy Commons

\section{Recommended Citation}

Goertz, Margaret E. and Duffy, Mark. (2001). Assessment and Accountability Across the 50 States. CPRE Policy Briefs.

Retrieved from https://repository.upenn.edu/cpre_policybriefs/16

View on the CPRE website.

This paper is posted at ScholarlyCommons. https://repository.upenn.edu/cpre_policybriefs/16

For more information, please contact repository@pobox.upenn.edu. 


\title{
Assessment and Accountability Across the 50 States
}

\author{
Abstract \\ In recent years, all 50 states have embarked on education initiatives related to high standards and \\ challenging content. A central focus of these efforts has been the establishment of a common set of \\ academic standards for all students, the assessments that measure student performance, and \\ accountability systems that are at least partially focused on student outcomes. This CPRE Policy Brief \\ summarizes a longer report about state assessment and accountability systems in all 50 states and \\ examines the extent to which state policies meet the intent of federal policy, particularly Title I.

\section{Disciplines} \\ Educational Assessment, Evaluation, and Research | Education Policy \\ Comments \\ View on the CPRE website.
}




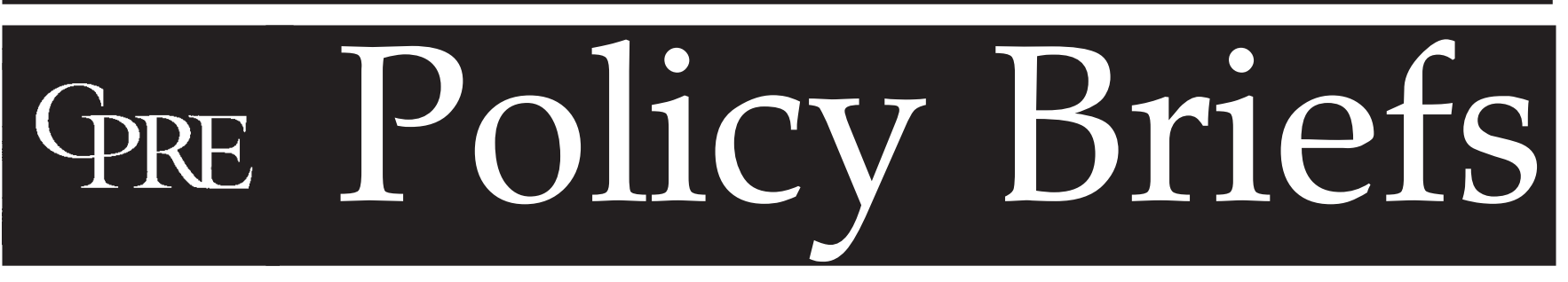

Reporting on issues in education reform

RB-33-May 2001

\section{Assessment and Accountability Across the 50 States}

\section{by Margaret E. Goertz and Mark C. Duffy}

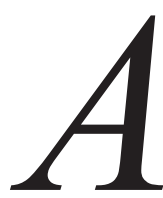

cross the United States, policymakers and educational leaders are implementing accountability and assessment measures in response to increasing concerns about and calls for improving student performance. What is becoming apparent, however, is that states are interpreting the call in different ways. Although their policies vary, states face similar challenges in creating effective and equitable accountability systems.

\section{Overview}

In recent years, all 50 states have embarked on education initiatives related to high standards and challenging content. A central focus of these efforts has been the establishment of a common set of academic standards for all students, the assessments that measure student performance, and accountability systems that are at least partially focused on student outcomes. This CPRE Policy Brief summarizes a longer report about state assessment and accountability systems in all 50 states and examines the extent to which state policies meet the intent of federal policy, particularly Title I.

We focused on the following questions:

- How are states measuring student performance and reporting it to the general public?

- How are states holding schools, school districts, and students accountable for student outcomes?

- How aligned are accountability policies for Title I and non-Title I schools?

- How are states assisting low-performing schools?

The Consortium for Policy Research in Education (CPRE) studies alternative approaches to education reform in order to determine how state and local policies can promote student learning. Currently, CPRE's work is focusing on accountability policies, efforts to build capacity at various levels within the education system, methods of allocating resources and compensating teachers, and governance changes like charters and mayoral takeover. The results of this research are shared with policymakers, educators, and other interested individuals and organizations in order to promote improvements in policy design and implementation. CPRE is funded by the National Institute on Educational Governance, Finance, Policymaking, and Management, Office of Educational Research and Improvement, U.S. Department of Education.

\section{CONSORTIUM FOR POLICY RESEARCH IN EDUCATION \\ University of Pennsylvania - Harvard University • Stanford University University of Michigan • University of Wisconsin-Madison}


- What challenges do the federal government and the states face in designing effective and equitable accountability and improvement systems?

The study was based on information drawn from a 50-state survey of state assessment and accountability systems conducted by CPRE between February and June 2000.

\section{Measuring Student Performance}

Forty-eight states use a state assessment as their principal indicator of school performance. The two other states, Iowa and Nebraska, require their districts to test students in specified grades or grade spans, but leave the choice of assessment instrument to the locality.

The Improving America's Schools Act (IASA) of 1994 requires that states test students at least once during each of three grade spans: third-to-fifth, sixth-to-ninth, and tenth-to-twelfth. But we found that states assess students considerably more often with some states testing students in almost every grade. The states fell into one of three categories in 1999-2000:

- The majority of states test students in a single grade per subject at each of three levels: elementary, middle, and high school.

- Twelve states test consecutive grades between grades 2 or 3 and at least grade 8 in the same subject areas using the same assessment.

- Three states test consecutive grades between grades 2 or 3 and 8 in different subjects and/or using multiple assessments.

Although most state assessment systems begin in the third grade, seven states have developed assessments for earlier grades as a way of identifying and diagnos- ing problems in student learning early in a child's career. Other states require districts to test reading in early grades.

Twenty-nine states administer a combination of criterion-referenced and norm-referenced tests. Seventeen states use only criterion-referenced tests and two states use only norm-referenced assessments. Only one in five states now have their own local testing requirements, a result of the expansion of state testing programs.

\section{Assessing Students with Special Needs}

States face both technical and political challenges as they bring students with disabilities and students with limited-English proficiency into their assessment systems. States want to include special student populations both to improve the quality of educational opportunities afforded all students, and to provide useful information about the performance of special needs students to parents and the public.

States report testing more students with disabilities and offer a range of test accommodations and modifications, but face challenges in developing and implementing alternative assessments. They have a variety of policies regarding whether and when English-language learners are included in state assessments. Some exempt English-language learners based on the length of their residency, some based on time in an Englishas-a-Second-Language or bilingual program, and some based on their level of English proficiency determined by a separate assessment.

\section{Setting Student Performance Levels}

Title I requires states to establish at least three levels of student performance on state assessments-advanced, proficient, and partially proficient — in order to show how well students are mastering the material

CPRE Policy Briefs are published by the Consortium for Policy Research in Education (CPRE). The research reported in this brief was conducted by CPRE. Funding for this work was provided by the U.S. Department of Education's National Institute on Educational Governance, Finance, Policymaking, and Management (Grant \#OERIR308A60003). Opinions expressed in this brief are those of the authors, and do not necessarily reflect the views of the National Institute on Educational Governance, Finance, Policymaking, and Management; the Office of Educational Research and Improvement; the U.S. Department of Education; or the institutional partners of CPRE. 
in the state content standards. Nearly all of the states with statewide assessments had student performance levels in place for the 2000-2001 school year. Most have created four-to-five levels for student performance, generally adding an additional category of partial proficiency. States use these performance categories for multiple purposes, including student reporting, retention, and awarding high school diplomas.

A majority of states also collect additional information on student performance including attendance, dropout, and graduation rates.

\section{Reporting and Disaggregating Student Performance}

Public reporting of programs and performance is the most basic form of school accountability. This gives the public information to seek improvements or to choose alternative schools for their children.

Currently, all 50 states produce or require local school districts to publish district or school report cards. School report cards, prepared in 40 states, include, at a minimum, information on student performance on state and/or local assessments. Public reports usually include information on non-cognitive measures such as student attendance, dropout rates, and graduation rates as well as indicators of school climate, teacher quality, and fiscal resources. Data are commonly reported on school discipline, safety and climate, teacher qualifications and experience, class size or studentteacher ratios, and financial information such as perpupil expenditure.

Thirty-nine states with statewide assessment systems report that they disaggregate test data by race/ethnicity and gender, a requirement of Title I. Many states also disaggregate data in such categories as socio-economic status, English proficiency, or free or reduced lunch status, but do not always report this information to the public.

\section{Holding Schools, Districts, and Students Accountable}

State accountability systems create incentives for students, schools, and school districts to focus on student achievement and continuous progress. The type and strength of these incentives are determined largely by the design of the accountability system, particularly who sets what goals for the system, the measures of adequate progress, and the consequences of meeting or not meeting these goals. State accountability systems fall into three basic categories.

State-defined accountability systems. Thirty-three states set performance goals for schools or districts and hold these units directly accountable for meeting these outcome goals. These states also establish rewards for meeting or exceeding state goals, sanctions for not meeting their targets, or both. The state performance goals vary along several dimensions, including how performance is measured and whether the performance goal is fixed or relative.

Public reporting. Thirteen states use public reporting as their primary accountability mechanism.

Locally-defined accountability systems. A few states have accountability systems that emphasize local standards and planning. These states allow districts to establish criteria for school performance, but use strategic plans or district and school improvement plans to hold districts accountable for student performance.

\section{Setting Performance Targets and Goals for Schools}

A key component of standards-based reform is establishing challenging standards for all students. Accountability systems are largely designed to ensure that schools and school districts make continuous and substantial progress, within an appropriate timeframe, toward the goal of all students meeting state levels of proficiency and advanced achievement. However, there is wide variation in school performance goals among the 33 states with state-defined accountability systems.

Most states expect to bring some or all students to proficient levels of performance. The measure of proficiency, however, is not comparable across states. States use different assessments aligned with different standards and set different cut scores for different performance levels. States also differ in the percentage of students that are expected to meet basic or proficient standards and set different timelines for meeting their performance goals. 


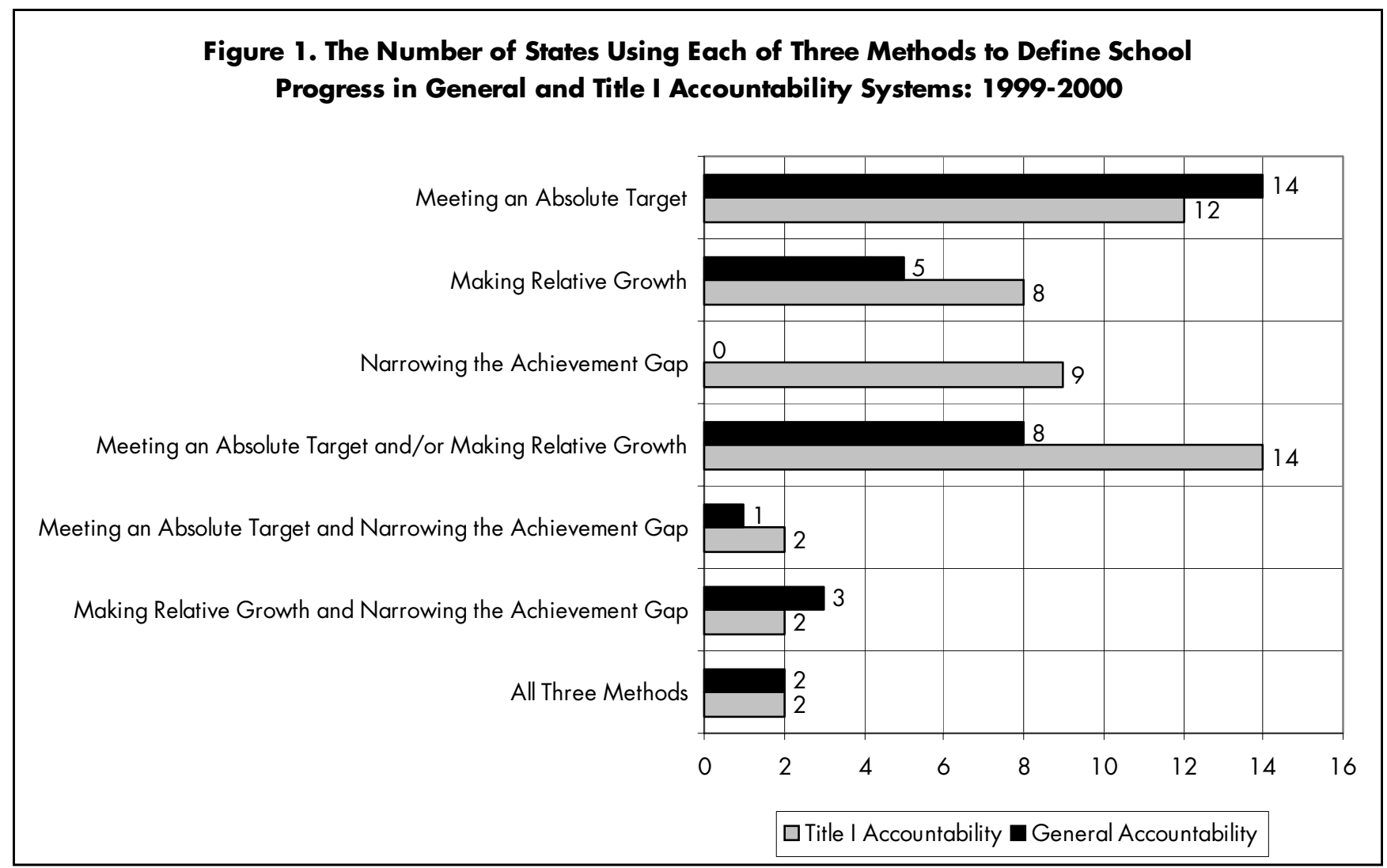

\section{Defining Progress}

Once states have identified performance measures and established performance goals, they must determine how they will measure annual progress toward these goals. Title I requires states to define what they consider substantial and continuous progress toward performance goals. Using these definitions of adequate yearly progress, states must then identify schools and districts in need of improvement.

States use at least one of three approaches to measure school progress:

- Meet an absolute target: achieve a performance threshold that all schools must attain to have made satisfactory progress;

- Make relative growth: meet an annual growth target that is based on each school's past performance and often reflects its distance from state goals; and/ or

- Narrow the achievement gap: reduce the number or percentage of students scoring in the lowest performance levels.
As we see in Figure 1, states differ in the type and mix of measures they use in defining school progress. In addition, states are more likely to incorporate measures of continuous progress - relative growth or narrowing the achievement gap - in their Title I than in their general accountability systems. Only a few states hold schools accountable for the performance of specific groups of students, such as racial/ethnic minorities or economically-disadvantaged students.

\section{Creating Consequences for Performance: Carrots and Sticks}

Accountability systems create incentives for school improvement by defining and measuring performance outcomes and progress, and by attaching consequences to these outcomes. Consequences for students, schools, and school districts vary across states, depending on the locus of authority (state versus local) and the state's willingness and capacity to intervene in low-performing schools.

Consequences for schools. Most states direct rewards and sanctions to the school level. All 33 states with state-defined accountability systems identify low-performing schools and have some provision for assis- 
tance, from either the state or local school district, as well as sanctions to schools that fail to improve after a specified period of time. In some states, schools receive financial rewards for high levels of performance or improvement. A majority of the 33 states require low-performing schools to develop improvement or action plans that identify strategies to address their areas of weakness.

Consequences for districts. States have been slower to develop district-level systems of accountability; only 17 states hold districts accountable for student or school performance.

Consequences for students. As states have implemented school-based accountability systems, educators and policymakers have begun to question the lack of student incentives in these policies. Teacher success is dependent on student efforts in school, but there is nothing in school-based accountability systems that motivates students to take the tests seriously, especially in secondary schools. Nor are there any consequences for students who perform poorly on the tests.

In response to this, several states have enacted promotion gates: students cannot progress to the next grade if they do not meet district or state performance standards. By 2008, students in 28 states will have to pass a state examination to graduate from high school. Political and community opposition to high stakes for students has developed in some of these states.

\section{Aligning Accountability Systems with Title I}

The intent of IASA was to create single and "seamless" accountability systems that would treat all schools equally. States were expected to develop aligned systems of high standards, challenging assessments, and accountability, and then align their Title I programs with these policies. We found, however, that only 22 states will have a single or unitary accountability system in place by 2000-2001. In these systems, all schools and/or districts are held to the same performance standards regardless of their Title I status. (See Table 1.)

Twenty-eight states operate dual systems of accountability in which either Title I and non-Title I schools are held accountable using different sets of indicators
Table 1. Alignment of Title I and General State Accountability Systems, 1999-2000

\begin{tabular}{|c|c|c|}
\hline State & Unitary Systems & Dual Systems \\
\hline Alabama & $x$ & \\
\hline Alaska & & $x$ \\
\hline Arizona & & $x$ \\
\hline Arkansas & & $x$ \\
\hline $\begin{array}{l}\text { California } \\
\text { Colorado }\end{array}$ & $x$ & $x$ \\
\hline Connecticut & $\mathrm{x}$ & \\
\hline Delaware' & $\mathrm{x}$ & \\
\hline Florida & $x$ & \\
\hline Georgia $^{3}$ & & $x$ \\
\hline Hawaii & & $x$ \\
\hline Idaho & & $x$ \\
\hline $\begin{array}{l}\text { Illinois }{ }^{3} \\
\text { Indiana }\end{array}$ & $\mathrm{x}$ & \\
\hline lowa & $x$ & $x$ \\
\hline Kansas $^{3}$ & & $\mathrm{x}$ \\
\hline Kentucky & $x$ & \\
\hline Louisiana & $x$ & \\
\hline Maine $^{2}$ & & $\mathrm{x}$ \\
\hline Maryland & $x$ & \\
\hline Massachusetts ${ }^{1}$ & $x$ & \\
\hline Michigan & & $\mathrm{x}$ \\
\hline Minnesota & & $x$ \\
\hline Mississippi & & $x$ \\
\hline Missouri & & $x$ \\
\hline Montana & & $x$ \\
\hline Nebraska & & $x$ \\
\hline Nevada & & $x$ \\
\hline New Hampshire 2 & & $x$ \\
\hline New Jersey & & $x$ \\
\hline New Mexico 3 & $\mathrm{x}$ & \\
\hline New York ${ }^{3}$ & $x$ & \\
\hline North Carolina & $x$ & \\
\hline North Dakota & & $x$ \\
\hline Ohio & $\mathrm{x}$ & \\
\hline Oklahoma & & $x$ \\
\hline Oregon ${ }^{2}$ & $x$ & \\
\hline Pennsylvania & & $x$ \\
\hline Rhode Island & $x$ & \\
\hline South Carolina & & $\mathrm{x}$ \\
\hline South Dakota & & $\mathrm{x}$ \\
\hline Tennessee & & $x$ \\
\hline Texas & $x$ & \\
\hline Utah & & $\mathrm{x}$ \\
\hline Vermont ${ }^{1}$ & $x$ & \\
\hline Virginia & $x$ & \\
\hline Washington & & $x$ \\
\hline West Virginia & $\mathrm{x}$ & \\
\hline Wisconsin & $x$ & \\
\hline Wyoming ${ }^{1}$ & & $\mathrm{x}$ \\
\hline
\end{tabular}

1. Planned to be implemented in 2000-2001.

2. Planned to be implemented in 2000-2001, pending federal approval.

3. Planned to be implemented in 2000-2001, pending state board approval. 
and/or performance standards, or only Title I schools are held accountable outside of the performance reporting structure.

\section{Assisting Low-Performing Schools}

In most of the unitary accountability systems, states identify schools that do not make adequate yearly progress for program improvement. In states without a state-defined accountability system, only Title I schools are targeted for improvement.

Under IASA, districts have the primary responsibility for assisting schools that have been identified for program improvement. States provide various forms of assistance to low-performing schools. The mix and level varies across states and districts, but we have identified four primary kinds of assistance.

Support in school improvement or corrective action planning. State departments of education provide needs assessments, on-site evaluations, assistance and training in data analysis, and other forms of technical assistance to help schools and districts create school improvement plans that identify weaknesses and strategies for improvement.

Financial assistance. Some states offer additional funding for the school improvement planning process and other school improvement initiatives.

Expert assistance in planning and instruction. State and local education officials and teachers provide technical assistance on best practices and staff development at school or district sites.

State- or regionally-sponsored professional development. States create professional development programs for administrators and staff from low-performing schools.

Finally, states draw on multiple resources in providing assistance to schools including the use of school improvement or support teams, distinguished educators who serve as school coaches, state department of education staff members who make regular monitoring visits and provide assistance, and regional and external service providers.

\section{Conclusion}

This policy brief shows that state responses to calls for performance-based accountability have not been uniform. State accountability systems have common elements - assessments, standards, performance reporting and, in most cases, consequences of performance-but states have found different ways to define what it means for schools to succeed, what indicators to include in their definition of success, and what the consequences will be. These variations reflect differences in state demographics, political culture, educational governance structures and policies, and educational performance. This raises important issues for educational leaders, policymakers, and interested consumers.

Accountability. Many states apply dual accountability systems to Title I and non-Title I schools instead of the intended single and "seamless" accountability system that would treat all schools the same, an IASA goal. Also, some states have not set specific performance goals or have not identified low-performing schools.

Assessment. State assessments are the cornerstone of state accountability systems. Policymakers face three challenges in developing assessments that are valid and politically acceptable measures of student performance.

First, what is the appropriate mix of norm-referenced and criterion-referenced items in an assessment, and how can states determine which items are aligned with state standards and should be used to hold schools and districts accountable for student performance?

Second, the federal government expects states to include multiple measures of student performance in their high-stakes accountability systems, but policymakers and the education community do not have a clear or common understanding of what this means. The case of multiple measures takes on even greater importance when making high-stakes decisions about individual students.

Third, policymakers face an increasing public backlash in this new high-stakes environment of student testing. 
Equity. Important questions of equity exist as states determine which students are tested under what conditions, and ask if all students have access to teachers with a strong content knowledge and to the academic program they need in order to meet the new academic standards. Closing the achievement gap requires addressing inequities that exist in opportunities to learn to high standards.

Capacity. Finally, policymakers need to consider if states and districts have the capacity to support the school improvement efforts of struggling and failing schools. States and districts need knowledge, human resources, and financial resources to turn around poorly-performing schools. Although we are learning more about how to work with low-performing schools, we need considerably more research on the roles that states and districts play and on the kinds of assistance they provide to schools in need.

\section{About the Authors}

Margaret Goertz, CPRE's Co-Director for policy and governance, is a Professor in the Graduate School of Education, University of Pennsylvania. Goertz is a policy analyst specializing in the fields of education policy, governance, and finance. She has conducted extensive research on state education reform policies, state teacher testing policies, and state and federal programs for special needs students. Goertz has just completed a multi-year study of standards-based reform in eight states.

Mark Duffy is a researcher with CPRE at the University of Pennsylvania. His primary responsibilities have included coordinating the project, "State and Local Education Policy Reform: From Congress to the Classroom," conducting research and analysis on assessment and accountability systems in the 50 states, and most recently working on an evaluation of New American Schools district services.

\section{More on the Subject}

Copies of profiles of state assessment and accountability policies, and the full-length report based upon this study are available for download from CPRE's web site: www.gse.upenn.edu/cpre/. Copies of the report are also available for purchase. Ordering instructions follow.

\section{New CPRE Publications}

Assessment and Accountability Systems in the 50 States: 1999-2000

Margaret E. Goertz and Mark C. Duffy

March 2001, RR-046, Cost: \$5

State responses to calls for performance-based accountability have not been uniform. This comprehensive report outlines the similarities and variations across the 50 states. Goertz and Duffy found that many states apply dual accountability systems to Title I and non-Title I schools instead of the intended single accountability system which was a goal of the Improving America's Schools Act of 1994. The study raises important issues for educational leaders, policymakers, and interested consumers.

\section{Moving Mountains: Successes and Challenges of the America's Choice Comprehensive School Reform Design}

Jonathan A. Supovitz, Susan M. Poglinco, and Brooke A. Snyder

March 2001, No charge

Much early evidence indicates that the America's Choice school reform design is having a positive impact on student achievement. This thorough report provides a detailed description and analysis of both the implementation and the impact of the design.

To obtain copies, write to: CPRE Publications, Graduate School of Education, University of Pennsylvania, 3440 Market Street, Suite 560, Philadelphia, PA 19104-3325. Make checks payable to Trustees of the University of Pennsylvania. Prices include handling and book-rate postage. Sorry, we cannot accept returns, credit card orders, or purchase orders. All orders must be prepaid with U.S. funds from U.S. banks. Sales tax is not applicable. Please allow 2-3 weeks for delivery. For more information, please call (215) 573-0700, x233. 


\section{About CPRE}

The Consortium for Policy Research in Education (CPRE) unites five of the nation's leading research institutions to improve elementary and secondary education through research on policy, finance, school reform, and school governance. Members of CPRE are the University of Pennsylvania, Harvard University, Stanford University, the University of Michigan, and the University of Wisconsin-Madison.

CPRE conducts research on issues such as: education reform, student and teacher standards, state and local policymaking, education governance, school finance, teacher compensation, and student incentives.

To learn more about CPRE research or publications, please call (215) 573-0700.

\section{World Wide Web:}

www.gse.upenn.edu/cpre/

www.wcer.wisc.edu/cpre/

www.sii.soe.umich.edu

\section{Nondiscrimination Statement}

The University of Pennsylvania values diversity and seeks talented students, faculty, and staff from diverse backgrounds. The University of Pennsylvania does not discriminate on the basis of race, sex, sexual orientation, religion, color, national or ethnic origin, age, disability, or status as a Vietnam Era Veteran or disabled veteran in the administration of educational policies, programs, or activities; admissions policies, scholarships, or loan awards; and athletic or University administered programs or employment. Questions or complaints regarding this policy should be directed to Executive Director, Office of Affirmative Action, 1133 Blockley Hall, Philadelphia, PA 19104-6021 or (215) 898-6993 (Voice) or (215) 898-7803 (TDD).

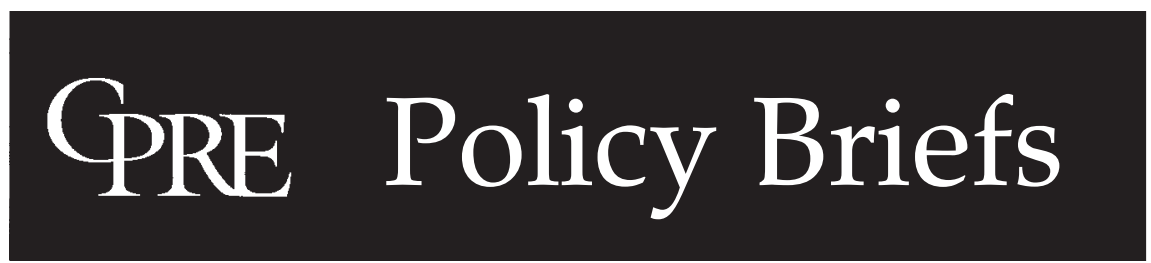

NON PROFIT

U.S. POSTAGE

PAID

PERMIT NO. 2563

PHILADELPHIA, PA

Graduate School of Education

University of Pennsylvania

3440 Market Street, Suite 560

Philadelphia, PA 19104-3325 